\title{
Studies on egg development in the Fennoscandian Isoperla species (Plecoptera)
}

\author{
S.J. Saltveit ${ }^{1}$ \\ A. Lillehammer'
}

Three species of $I$ soperla occur in Fennoscandia. The most common is $I$. grammatica, although it has not been recorded above the subalpine vegetation belt. I. difformis has a similar distribution, but is less common. I. obscura occurs mainly at high latitudes and altitudes, although it is also abundant in large rivers.

Eggs were reared at temperatures of $4,8,12,16,20$ and $24^{\circ} \mathrm{C}$. I. difformis did not hatch at $4^{\circ} \mathrm{C}, I$. grammatica at 4 and $8^{\circ} \mathrm{C}$ while $I$. obsctura did not hatch at $16^{\circ} \mathrm{C}$ and above. Egg mortality was high in 1 . difformis at $24^{\circ} \mathrm{C}$. Incubation period decreased with increase in temperature and varied between 28 and 68 days in $I$. grammatica and between 15 and 83 days in $I$. difformis. For $I$. grammatica and $I$. difformis, the relationship between the egg incubation period and the water temperature was linear on logarithmic scales. For 1 . obscura, no such relationship was found and the mean incubation period at all temperatures was $305 \pm 57$ (S.D.) days. Explanations are presented to explain these differences in egg incubation characteristics.

Etudes sur le développement des ceufs des espèces finnoscandinaves d'Isoperla (Plecoptera).

Trois espèces d'Isoperla vivent en Finnoscanctinavie. La plus commune est $I$. grammatica. bien qu'elle ne se rencontre pas au-dessus de l'étage subalpin. $l$. difformis présente une méme distribution mais est moins conmune. $l$. obscura se trouve surtout à des latitudes et altitudes élevées bien qu'elle soil aussi abondante dans les grandes rivieres.

Des oeufs furent placés à des températures de $4,8,12,16,20$ et $24^{\circ} \mathrm{C}$. $l$. difformis n'éclôt pas à $4^{\circ} \mathrm{C}, I$. grammatica à 4 et $8^{\circ} \mathrm{C}$ et il en est de mème d' $I$. obsctura à $16^{\circ} \mathrm{C}$. La mortalité des ceufs d' $I$. difformis est élevee à $24^{\circ} \mathrm{C}$. La durée d'incubation décroit quand la température augmente et varie entre 28 et 68 jours pour 1 . grammatica et entre 15 et 83 jours pour 1 . difformis. Pour ces deux espèces, la relation en tre la durée d'incubation et la température est linéaire en coordonnées logarithmiques. Cette relation n'existe pas poụ l. obscura et l'incubation dure $305 \pm 57$ (écart tỵpe) jours à toutes les temperatures. Les auteurs proposent des explications de ces différences

\section{Introduction}

Three species of lsoperla occur in Fennoscandia : I. difformis, I. grammatica and I. obscura (Brinck 1949). I. grammatica is the most common in Norway, occuring in all kinds of streams and rivers, but not in lakes. However, this species does not occur above the subalpine vegetation belt, situated at about $1100 \mathrm{~m}$ a.s.l. in southern Norway (Lillehammer 1974). I. difformis has a similar distribution, but is far less common and has not been recorded above $700 \mathrm{~m}$ a.s.l. In northern Norway I. obscura is com-

1. Zoological Museum, University of Oslo, Sarsgt 1. Osto S. Norway. mon in all kinds of freshwater environments, but in the southern parts of Norway the species is only common in high altitude localities, except for large lowland rivers. This is the only Isoperla species which has been recorded in the mid-alpine vegeta. tion belt, being recorded up to about $1500 \mathrm{~m}$ a.s.l. in southern Norway.

In an at tempt to obtain a better understanding of the distribution and environmental strategies of Norwegian stoneflies, egg incubation and growth studies are being carried out in the laboratory on different species. Through these studies we hope to be able to categorize different types of egg development and nymphal growth patterns in stoneflies. Previous contributions to our synthesis (see Lillehammer et al., this volume) include the studies by Lillehammer 1975, 1976, Brittain 1978, 1983, Brit- 
tain et al. 1984 and Saltveit 1977, as well as these studies on Isoperla.

Temperature is a major factor influencing stonefly distribution (Lillehammer 1974). Distribution patterns of species may therefore be in part explained by their capability to adapt their life cycle strategies to different kinds of temperature regimes. Controlled laboratory studies enable us to assess development time and temperature requirement of the different life cycle stages. This paper presents data on the temperature requirements and limitations for the egg stage of $I$. difformis, I. grammatica and $I$. obscura.

\section{1. - Methods}

Adult Isoperla, along with sufficient water for egg incubation studies, were collected from the field sites, Saeterbekken ( $110 \mathrm{~m}$ a.s.l.) and Sörkedalselva ( $125 \mathrm{~m}$ a.s.l.) in the Oslo region $\left(60^{\circ} 00^{\prime} \mathrm{N}, 10^{\circ} 30^{\prime} \mathrm{E}\right.$ ) ) and Valdresflya (1 $400 \mathrm{~m}$ a.s.l.) in the Jotunheimen mountains $\left(61^{\circ} 25^{\prime} \mathrm{N}, 8^{\circ} 52^{\circ} \mathrm{E}\right)$, during the emergence period. The adults were transported to the laboratory where they were kept in small plastic boxes placed in constant temperature cabinets at $10^{\circ} \mathrm{C}$. On most days the boxes were transferred to $20^{\circ} \mathrm{C}$ for a few hours to increase the chance of mating and oviposition. Each box contained a small Petri dish with water from the field site, together with small twigs and leaves, which provided shelter. The boxes were inspected daily and any egg batches removed and counted, before being placed at constant temperatures at $4^{\circ} \mathrm{C}$ intervals between 4 and $24^{\circ} \mathrm{C}$. All egg batches were incubated in total darkness and were inspected daily for hatching. The duration of egg incubation at the various temperatures was taken as the period in days from oviposition until $50 \%$ of the eggs that eventually hatched in any one batch had hatched

\section{2. - Results}

In $I$. difformis no hatching occured at $4^{\circ} \mathrm{C}$ (Table I). At $8^{\circ} \mathrm{C}$ the egg incubation period was about 80 days with a hatching success of $90 \%$. The mean incubation period decreased with increasing temperature, being $15-20$ days at $20-24^{\circ} \mathrm{C}$. The low hatching success in some of the egg batches was due to fungal infections.

The eggs of 1 . grammatica did not hatch at 4 and $8^{\circ} \mathrm{C}$, while the mean incubation period at $12^{\circ} \mathrm{C}$ was 54 days and decreased with increasing temperature (Table II). However, the differences were small between 16 and $24^{\circ} \mathrm{C}$. The hatching success was high
Table I. Egg incubation data for individual egg batches from Isoperla difformis from Saeterbekken, showing incubation temperature $\left(\mathrm{T}^{\circ} \mathrm{C}\right)$, number of eggs (n), days for first egg to hatch, mean (50 \%) incubation period in days, duration of hatching in days and percentage hatching success.

\begin{tabular}{|c|c|c|c|c|c|}
\hline $\mathbf{T}^{\circ} \mathrm{C}$ & $\pi$ & $\begin{array}{c}\text { First egg } \\
\text { to hatch } \\
\text { (days) }\end{array}$ & $\begin{array}{c}\text { Incubation } \\
\text { period } \\
\text { (days) }\end{array}$ & $\begin{array}{l}\text { Duration } \\
\text { of hatching } \\
\text { (days) }\end{array}$ & $\stackrel{\%}{\text { hatching }}$ \\
\hline 4 & 35 & - & - & - & 0.0 \\
\hline 4 & 44 & - & - & - & 0.0 \\
\hline 8 & 198 & 76 & 81 & 18 & 88.4 \\
\hline 8 & 90 & 80 & 83 & 19 & 94.4 \\
\hline 12 & 87 & 40 & 43 & 2 & 77.0 \\
\hline 12 & 27 & 42 & 46 & 5 & 25.9 \\
\hline 16 & 67 & 27 & 28 & 3 & 76.1 \\
\hline 16 & 213 & 28 & 28 & 4 & 2.3 \\
\hline 21 & 40 & 19 & 19 & 1 & 95.0 \\
\hline 21 & 135 & 14 & 15 & 7 & 97.8 \\
\hline 24 & 117 & 17 & 20 & 15 & 16.2 \\
\hline
\end{tabular}

Table II. Egg incubation data for individual egg batches from Isoperla grammatica from Sörkedalen, showing incubation temperature $\left(T^{\circ} \mathrm{C}\right.$ ), number of eggs (n), days for first egg to hatch, mean (50\%) incubation period in days, duration of hatching in days and percentage hatching success.

\begin{tabular}{rrcccr}
\hline \multicolumn{7}{c}{$T^{\circ} \mathrm{C}$} & $\mathrm{n}$ & $\begin{array}{c}\text { First egg Incubation } \\
\text { to hatch } \\
\text { (days) }\end{array}$ & $\begin{array}{c}\text { Duration } \\
\text { period } \\
\text { (days) }\end{array}$ & $\begin{array}{c}\% \\
\text { of hatching hatching } \\
\text { (days) }\end{array}$ \\
\hline 4 & 55 & - & - & - & 0.0 \\
8 & 24 & - & - & - & 0.0 \\
8 & 130 & - & - & - & 0.0 \\
12 & 94 & 50 & 52 & 3 & 97.9 \\
12 & 108 & 50 & 56 & 14 & 100.0 \\
12 & 160 & 50 & 55 & 20 & 100.0 \\
16 & 63 & 31 & 32 & 24 & 98.4 \\
16 & 78 & 30 & 31 & 20 & 100.0 \\
16 & 189 & 30 & 30 & 7 & 96.8 \\
16 & 199 & 30 & 32 & 16 & 99.5 \\
20 & 113 & 28 & 29 & 8 & 94.6 \\
20 & 117 & 28 & 28 & 12 & 100.0 \\
24 & 78 & 26 & 35 & 30 & 92.3 \\
24 & 79 & 26 & 33 & 29 & 93.8 \\
\hline
\end{tabular}

at all temperatures where hatching occurred (90-100\%).

Eggs of $I$. obscura hatched at 4,8 and $12^{\circ} \mathrm{C}$, but not at 16 and $20^{\circ} \mathrm{C}$ (Table III). However, the hat- 
Table III. Egg incubation data for individual egg batches from Isoperla obscura from Valdresflya, showing incubation temperature $\left(\mathrm{T}^{\circ} \mathrm{C}\right.$ ), number of eggs (n), days for first egg to hatch, mean (50\%) incubation period in days, duration of hatching in days and percent hatching success.

\begin{tabular}{|c|c|c|c|c|c|}
\hline $\mathrm{T}^{\circ} \mathrm{C}$ & $\mathrm{n}$ & $\begin{array}{l}\text { First egg } \\
\text { to hatch } \\
\text { (days) }\end{array}$ & $\begin{array}{l}\text { Incubation } \\
\text { period } \\
\text { (days) }\end{array}$ & $\begin{array}{l}\text { Duration } \\
\text { of hatching } \\
\text { (days) }\end{array}$ & $\begin{array}{c}\% \\
\text { hatching }\end{array}$ \\
\hline 4 & 140 & 321 & 337 & 86 & 75.7 \\
\hline 4 & 84 & 320 & 342 & 87 & 52.4 \\
\hline 4 & 63 & 310 & 332 & 87 & 92.1 \\
\hline 8 & 146 & 321 & 357 & 75 & 22.6 \\
\hline 8 & 201 & 316 & 334 & 83 & 28.4 \\
\hline 8 & 72 & 310 & 340 & 77 & 43.1 \\
\hline 12 & 43 & 320 & 326 & 49 & 7.0 \\
\hline 12 & 36 & 321 & 321 & 1 & 5.6 \\
\hline 12 & 150 & 327 & 327 & 1 & 2.0 \\
\hline 12 & 300 & . & 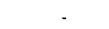 & . & 0.0 \\
\hline 12 & 60 & - & - & - & $0.0^{\circ}$ \\
\hline 16 & 100 & - & - & - & 0.0 \\
\hline 16 & 100 & - & - & - & 0.0 \\
\hline 16 & 75 & - & - & - & 0.0 \\
\hline 20 & 30 & - & - & - & 0.0 \\
\hline 20 & 43 & - & - & . & 0.0 \\
\hline
\end{tabular}

ching success at $12^{\circ} \mathrm{C}$ was very low. At 4 and $8^{\circ} \mathrm{C}$ a very long and similar incubation period was found, varying between 332 and 357 days at both temperatures. The highest hatching success was at $4^{\circ} \mathrm{C}$.

For both $I$. difformis and $I$. grammatica the relationship between the egg incubation period ( $\mathrm{Y}$ days) and temperature $\left(\mathrm{T}^{\circ} \mathrm{C}\right)$ was highly significant, respectively $P<0.001$ and $P<0.01$. The relationship was linear on logarithmic scales and well expressed by the equation :

$$
\begin{gathered}
\log \mathrm{Y}=\log \mathbf{a}-\mathbf{b} \log \mathrm{I} \\
\quad \text { or } \\
\mathrm{Y}=\mathrm{a} \mathrm{T}^{-b}
\end{gathered}
$$

Values of the constants $\mathrm{a}$ and $\mathrm{b}$ are given in Fig. 1 .

For $l$. obscura no significant relationship was found between the egg incubation period (Y-days) and temperature $\left(\mathrm{T}^{\circ} \mathrm{C}\right)$. Thus egg development seems independent of temperature in the range tested.

\section{DAYS}

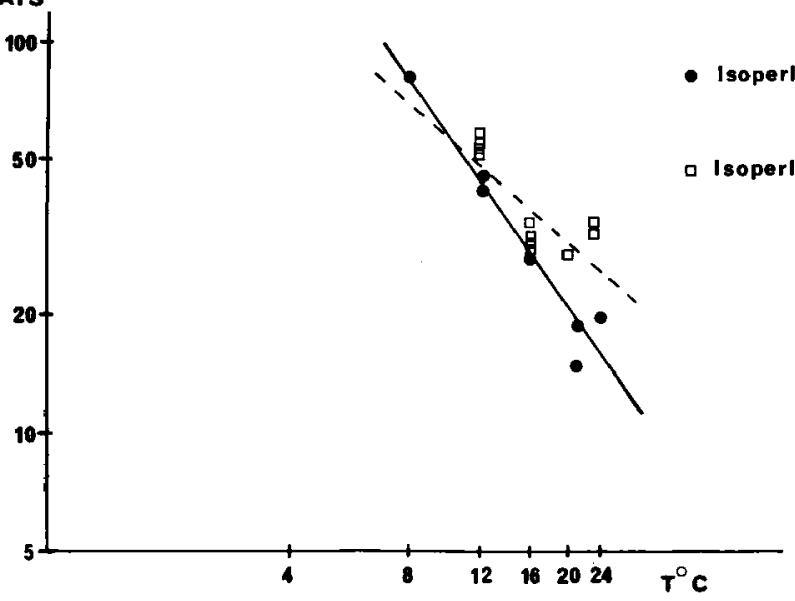

Fig. 1. The relationship between egg incubation period ( $Y$ days) and water temperature $\left(T^{\circ} \mathrm{C}\right)$ for 1 soperla difformis and Isoperla grammatica. The equations for the regression lines are given for both species. 


\section{3. - Discussion}

Egg development in both $I$. difformis and $I$. grammatica was highly temperature dependent, with a short incubation period. A similar basic relationship between temperature and incubation period has been found for other stonefly populations, such as Taeniopteryx nebulosa (Brittain 1977), Nemurella pictetii (Brittain 1978) and Capnia atra (Brittain et al. 1984). The intercepts are higher in both $I$. difformis and $I$. grammatica, meaning that they require more degree days for development than the other mentioned species. These Isoperla species seems therefore restricted to areas which are able to provide the required number of degree days for egg development in a relatively short period.

In $l$. obscura, however, development seems independent of temperature in the range tested. The development period in $I$. obscura is at least 10-11 months, but some eggs have a longer development time. The presence of small nymphs in late August and September almost at the same time as the adult emerge (Lillehammer, unpubl. data), support the laboratory results. We are uncertain about any diapause. However, in some preliminary studies eggs taken from 12 and $16^{\circ} \mathrm{C}$ in January and transfer. red to lower temperatures did have a higher hatching success, although the incubation period did not differ from that found at 4 and $8^{\circ} \mathrm{C}$. This is similar to the effect found when cooling down eggs of Amphinemura standfussi that did not hatch at 16 and $20^{\circ} \mathrm{C}$ (Saltveit 1977). However, a different effect was found in Diura nanseni where freezing broke egg diapause (Lillehammer 1976).

In Norway seven other species have a similar altitudinal distribution to l. obscura (Lillehammer 1974 , 1984). Five of these species have a long egg development time during the winter (winter eggs) (Lillehammer 1976, Saltveit 1977, unpubl. data), and this includes all the four predator species (Systellognatha) occurring in the area. These species are north to north-eastern immigrants to Fennoscandia, and were probably through immigration well adapted to these environments. However, except for Diura bicaudata similar life history patterns have so far been found in lowland areas (Lillehammer 1976, Saltveit 1977, unpubl. data). In D. bicaudata, occurring in Great Britain, both summer and winter eggs have been found (Khoo 1968).
I. grammatica and $I$. difformis, however, are southern immigrants to Fennoscandia, but show differences in morphology in far northern areas. Studies of the egg development in widely separated populations is necessary in order to provide answers to these questions concerning inter-and intraspecific variation in life history patterns. It would also be interesting to compare immigration history and egg development. Another interesting comparison would be one of the egg development types with phylogenetic location of the species and genera.

\section{Acknowledgement}

We are grateful to Dr. J.E. Brittain for valuable discussion and for improving the English.

\section{Lilerature cited}

Brinck (P.). 1949. - Studies on Swedish stoneflies. 'Jpusc. ent. Suppl. I/, 250 pp.

Brittain (J.E.) 1977. - The effect of temperature on the egg incu. bation period of Taeniopteryx nebulosa (Plecoptera). Oikos, 29 302-305

Brittain (J.E.). 1978. - Semivoltinism in mountain populations of Nemurella pictetii (Plecoptera). Oikos, $30: 1-6$

Brittain (J.E.). 1983. - The influence of temperalure on nymphal grouth rates in mountain stoneflies (Plecoptera). Ecology; 64 $440-446$.

Brittain (J.E), Lillehammer (A.) \& Saltveil (S.J.). 1984. - The effect of temperature on intraspecific variation in egg biology and nymphal size in the stonefly Capnia atra (Plecoptera). I. Anim. Ecol. 53 : 161-169.

Khoo (S.G.) 1968. - Experimental studies on diapause in stoneflies. I1. Eggs of Ditra bicaudata (L.). Proc. R. ent. Soc. Lond. A, $43: 40-48$.

Lillehammer (A.). 1974. - Norwegian stoneflies. II. Distribution and relationship to environment. Norsk ent. Tidsskr., 21 195-250.

Lillehammer (A.). 1975. - Norwegian stoneflies. IV. Laboratory studies on ecological factor influencing dist ribution. Non: $j$. Ent. $22: 99.108$.

Lillehammer (A.). 1976. - Norwegian stoneflies. V. Variation in morphological characters compared to differences in ecological factors. Nonw. J. Ent., $23: 161-172$.

Lillehammer (A.). 1984. - Distribution. seasonal abundance and emergence of stoneflies (Plecoptera) in the Ovre Heimdalen arca of the Norwegian Jotunheimen Mountains. Fauna Norve. gia, Ser. $B$.

Lillehammer (A.), Brittain (J.E.) \& Saltveit (S.J.). 1984. - Egg development, nymphal growth and distribution of Fenroscandian stoneflies (Plecoptera). (Abstract). Annls Limnol., 20 : 144.

Saliveit (S.J.). 1977. - [Field and laboratory studies on stoneflies (Plecoptera), with special emphasis on the genus Amphinemura (Ris)]. (In Norwegian). Unpubl. thesis. Univ. of Oslo. 244 pp. 